\title{
ロ蓋扁桃に転移した肺癌例
}

\author{
渡邊 昭化・片山 昭公・岡安 健至*
}

\section{Palatine Tonsillar Metastasis from a Small Cell Carcinoma of the Lung}

\author{
Akihito Watanabe, Akihiro Katayama and Kenji Okayasu \\ (Keiyukai Sapporo Hospital)
}

\begin{abstract}
Metastasis of a tumor to the tonsil is a rare event and moreover, prognosis is typically poor. Here, we will report a case with good prognosis where a palatine tonsillar tumor which had metastasized from a small cell carcinoma of the lung was surgically excised followed by the neck dissection.

A 70-year-old male had been in our hospital for treatment of lung carcinoma. Following a history of pharyngalgia for one month, he was sent to our division for examination. A tumor mass which was partially ulcerated, was revealed in the superior region of the left palatine tonsil. Tumefied submandibular lymph nodes were palpable. A histopathological examination of biopsy material taken from the left palatine tonsil resulted in the diagnosis of a small cell carcinoma. Since the primary tumor seemed to have been removed successfully and metastasis was not observed except in the palatine tonsil, the patient was treated by radical excision of the tumor, followed by the neck dissection. After surgery the patient underwent two courses of a combination chemotherapy with CDDP + VP16 + MMC, and subsequently left the hospital.
\end{abstract}

Twenty two months after surgery the patient remains stable without a relapse.

Key words : tonsillar metastasis, small cell carcinoma, radical operation

はじめに

口腔内悪性腫瘍のうち転移性腫瘍は約 $1 \%$ のみであり, 転移性口蓋扁桃腫瘍はさらにまれである11。今回我々は 肺小細胞癌の左口蓋扁桃転移症例に根治的治療を施行し， 現在のところ良好な経過を得ている症例を経験した。こ の症例を報告するとともに文献的考察を加え報告する.

70 歳, 男性.

\section{症例}

主訴 : 咽頭痛.

現病歴: 平成 8 年 5 月頃から咽頭痛を自覚した. 近医 内科受診時に胸部レントゲンで異常陰影(図 1 )を指摘さ
れ，当院外科を紹介された．喀痰細胞診では扁平上皮癌 を疑われた．当院外科に入院後も咽頭痛が消失しないた めに 5 月 30 日当科を紹介された.

既往歴 : 特記すべきことなし.

家族歴：特記すべきことなし.

耳鼻咽喉科的現症 : 左口蓋扁桃上極付近の突出と潰痬 を認めた(図 2 )。頸部リンパ節は䫣下部に腫脹したリン パ節を触知した。 その他は特に異常所見を認めなかった。 経過：平成 8 年 5 月 30 日左口蓋扁桃より生検した。 病 理検查結果は小細胞癌であった. 平成 8 年 6 月 4 日左肺 上葉切除と縦隔郭清術を施行した。病理検查結果は小細 胞癌であった．肺癌と中咽頭癌の重複癌を考慮していた 


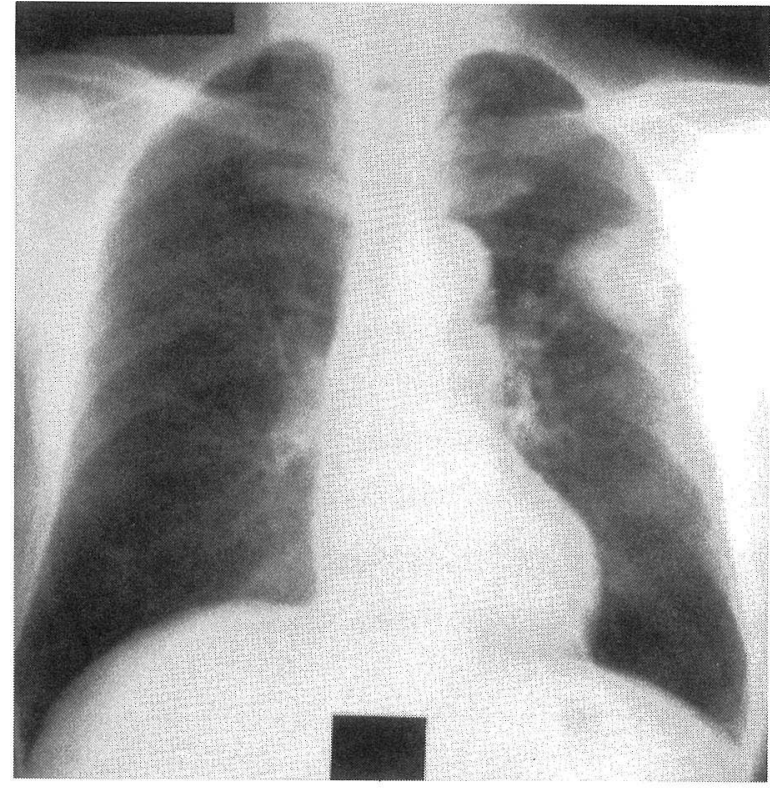

図 1 胸部レントゲン

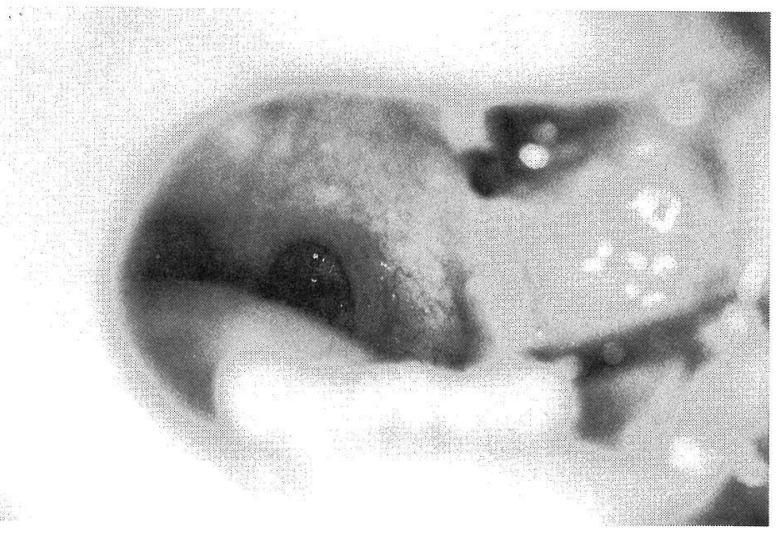

図 2 口腔内所見

が，病理組織的に肺癌の口蓋扁桃転移として矛盾しない とのことでめった(図 3 に肺腫瘍組織と扁桃より採取組 織を示した)。この時点で肺癌の切除が行なわれたこと， 他部位に転移が見られなかったことより口蓋扁桃腫瘍に 対し根治的治療を行うこととし，6月21日扁桃腫瘍摘出，

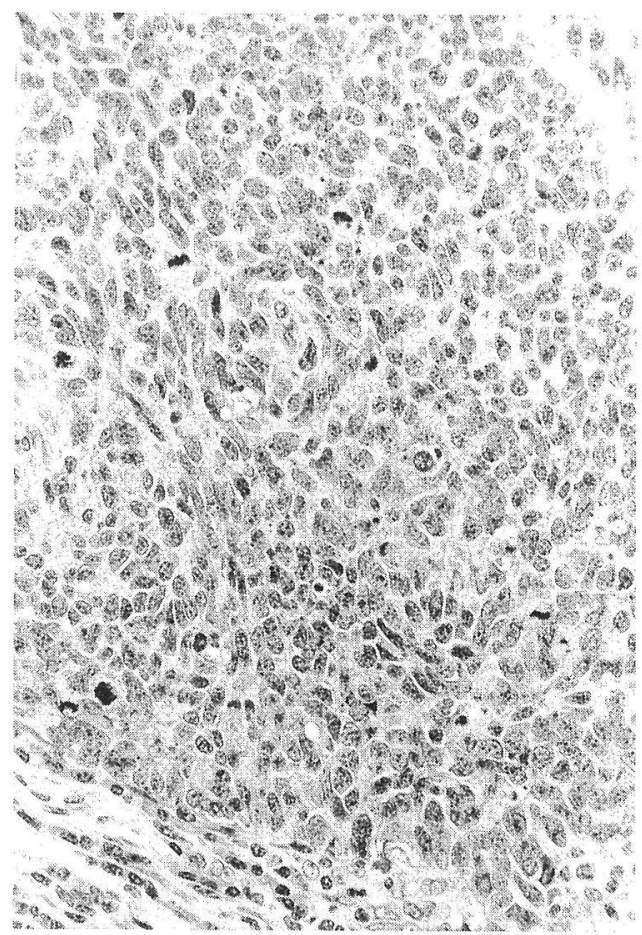

B

図 $3 \mathrm{~A}$ : 肺腫瘍組織(クロモグラニンA染色 $\times 100)$

$\mathrm{B}$ : 扁桃腫瘍組織(クロモグラニンA染色 $\times 100)$ 
左頸部郭清術を施行した。腫瘍は扁桃に限局しており周 囲筋組織への浸潤は見られなかった。郭清した頸部リン パ節には転移を認めなかった.術後の 7 月 8 日より CDDP (120 mg/body を 1 日目に投与) + VP16 (150 mg/body を 1 日目， 3 日目， 5 日目に投与 $)+M M C ~(12 \mathrm{mg} /$ body を 1 日目に投与) の化学療法を 2 クール行い 8 月 28 日退院 した. 退院後約 1 年経過した平成 9 年 7 月に脳転移を認 めたが放射線治療 (30 Gy) にてコントロールされている。 現在術後 1 年 10 力月経過しているが良好であり外来経過 観察中である.

\section{考察}

転移性口蓋扁桃腫瘍はまれであるといわれている(12). 本邦に批ける転移性口蓋扁桃腫瘍の報告例は我々が涉猟 しえた範囲では32例あり32 32)，自験例をいれて33例で あった．転移性腫瘍が少ない理由として 1 ) 口蓋扁桃に は輸入リンパ管がみられないことより転移しづらいこ $亡^{2)}, 2$ ) 口蓋扁桃は細網内皮系の細胞が主体で腫瘍排 除能力があること6)，などが考兄られている。

口蓋扁桃転移の転移経路については前述の輸入リンパ 管がないことから血行転移であららと考它られている。 その具体的な経路としては原発巣から肺を介して口蓋扁 桃転移とするものと, Batson 椎骨静脈叢を介しての転 移経路があるものと考学られている33). 自験例は原疾患 が肺癌であり，さらに周囲のリンパ節浸潤もなく，頸部 郭清術時のリンパ節検索でも転移が見られていないこと より, 左口蓋扁桃に直接血行転移したものとして矛盾し ないと考光ている。その他に肺癌の場合の転移形式とし て Brownson 5 ${ }^{34)}$ は気管支鏡の際に直接口蓋扁桃にイ ンプラテーションする可能性もあるのではと述べている。 原疾患について Brownson ら ${ }^{34)}$ は転移性口蓋扁桃腫 瘍76例の報告例の検討で悪性黒色腫13例, 肺癌12例, 腎 癌 11 例, 乳癌 11 例, 精上皮腫 6 例, 胃癌 5 例等の順で原 疾患がみられた。本邦に於ける報告例3) 32) では表 1 に みられるごとく肺癌10例(自験例を含む), 胃癌 8 例, 腎 癌 2 例, 肝癌 2 例, 大腸癌 2 例, 皮膚悪性黒色腫 2 例, 䋐毛癌 2 例, 胆囊癌 1 例, 膵臓癌 1 例, 乳癌 1 例, 甲状 腺癌 1 例，悪性中皮腫 1 例であった。本邦においては胃 癌の報告例が多く，腎癌，黒色腫の報告例が少ない傾向 が見られた。また，肺癌はいずれも高い頻度で見られて いた。

肺癌の口蓋扁桃転移症例を本邦報告例(3)10)11) 14)20025)26229)30)
表 1 本邦に於ける口蓋扁桃転移報告例の原発部位

\begin{tabular}{|c|c|c|}
\hline 原 & 発 & 症 例 数 \\
\hline \multicolumn{2}{|c|}{ 肺 } & 10 \\
\hline \multicolumn{2}{|c|}{ 胃 } & 8 \\
\hline 腎 & 臓 & 2 \\
\hline 肝 & 臓 & 2 \\
\hline 大 & 腸 & 2 \\
\hline 皮 & 膚 & 2 \\
\hline 絨 & 毛 & 2 \\
\hline 胆 & 囊 & 1 \\
\hline 膵 & 臓 & 1 \\
\hline 乳 & 腺 & 1 \\
\hline 甲 & 腺 & 1 \\
\hline 胸 & 膜 & 1 \\
\hline
\end{tabular}

(表 2 ) と Brownson ら ${ }^{34)}$ の検討例を比較してみると, 性別はいずれも男性のみであった，年齢は本邦では47歳 から70歳までで平均60歳で Brownson ら ${ }^{34)}$ の44歳から 71歳までで平均58歳と同様であった。転移側の検討では, 本邦報告例においては両側 3 例, 右 4 例, 左 3 例であり, Brownson ら ${ }^{34)}$ は両側 2 例で右左 5 例ずつであり注涪同 様であった．腫瘍細胞は本邦報告例は大細胞癌 4 例, 小 細胞癌 3 例, 腺癌 2 例, 不明 1 例であるが, Brownson ら ${ }^{34)}$ は 1 例の腺癌以外は小細胞癌であったと報告して いる。また，口蓋扁桃転移から死亡までの期間は本邦報 告例では自験例は生存しているため除外し, さらに生存 期間不明の 1 例を除外した 8 例の平均は 7 カ月であった. Brownson $5^{34)}$ は 5 カ月といずれも短期間であり予後は 非常に悪いといえる.さらに扁桃転移時点で他の部位の 転移が存在していたものは本邦報告例では不明の 1 例を 除き，他の 9 例はいずれも口蓋扁桃以外にも転移を認め

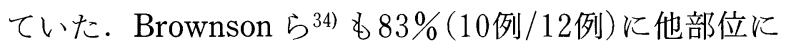
転移を認めて扣り，これが予後に大きく影響しているも のと思われた。

これら転移性頭頸部悪性腫瘍の治療方法については, 姑息的な治療方法がとられていることが多い．これは頭 頸部領域の転移は原発巣からの遠隔転移であること,さ らに前述のごとく頭頸部領域以外飞も転移を認めること が多いことが理由として挙げられると思われる。我々は 原疾患が制御されて抒り, 他に遠隔転移がないこと, 頭 
表 2 肺癌扁桃転移(本邦報告例)

\begin{tabular}{|c|c|c|c|c|c|c|c|c|c|}
\hline 報告年 & 報告者 & 年齢 & 性 & 扁桃転移側 & 組織 & 原発 $\rightarrow$ 扁桃 & 扁桃治療 & 他転移部位 & 予 後 \\
\hline 1956 & 斎藤3) & 69 & 男性 & 両側 & 肺癌 & 扁桃先行 & できず & 肝臓 & 2 力月死亡 \\
\hline 1983 & 宮原10) & 47 & 男性 & 左 & 大細胞 & 1 力月 & 放治 & 腰椎 & 6 力月死亡 \\
\hline 1985 & 周11) & 57 & 男性 & 右 & 大細胞 & 4 力月 & 化療 & 脳, 肋骨 & 10 力月死亡 \\
\hline 1987 & 森 ${ }^{14)}$ & 51 & 男性 & 左 & 腺癌 & 3 力月 & 化療 & 後腹膜, 胸腔 & 6 力月死亡 \\
\hline 1990 & 後藤20) & 50 & 男性 & 両側 & 大細胞 & 4 力月 & 化療＋放治 & 肺扁桃 & 6 力月死亡 \\
\hline 1992 & 永井25) & 67 & 男性 & 両側 & 大細胞 & 扁桃先行 & 化療 & 不明 & 死亡 \\
\hline 1993 & 松島26) & 52 & 男性 & 右 & 小細胞 & 9 力月 & 放治＋手術 & 肺 & 1 年死亡 \\
\hline 1995 & 中川 299 & 64 & 男性 & 右 & 腺癌 & 6 力月 & 化療 & 副腎, 腎, 肺 & 1 力月死亡 \\
\hline 1995 & 秋山 ${ }^{30)}$ & 70 & 男性 & 右 & 小細胞 & 1 年 4 力月 & 放治 & 肺, 脳 & 10 力月死亡 \\
\hline 1998 & 自験例 & 70 & 男性 & 左 & 小細胞 & 同時 & 手術＋化療 & 脳 & 22 力月生存 \\
\hline
\end{tabular}

頸部転移腫瘍が根治治療できる状態である場合には積極 的に治療を行いたいと考えている。ただし，抗癌剤に著 効が期待できる腫瘍等では他に遠隔転移がみられても根 治的治療態度で望むべきであるとも考光ている．自験例 は口蓋扁桃以外に遠隔転移がみられなかったこと, 頸部 リンパ節の軽度腫脹はみられたものの腫痬は口蓋扁桃に 限局していたことより根治的治療を行った。ただし，肺 小細胞癌は予後が悪い腫瘍であり ${ }^{35)}$ 今後も厳重な経過 観察と化学療法を継続する予定である.

医学の進歩によりこれまで延命, 長期生存が望めなか った症例も生存するよらになった。それにより今後転移 性頭頸部腫瘍を治療する機会が増えてくる可能性がある. 原発性腫瘍のみでなく転移性腫瘍も念頭に执き, 診断, 治療を進めていくことが必要であると思われる.

\section{参考論文}

1) Kutty MK and Shenoy AV : Metastatic choriocarcinoma of the tonsil following hysterectomy for an invasive mole and a period of "inactivity" of trophoblastic tissue ; report of a case. Oral Surg $32: 248 \sim 252,1971$.

2 ) Crawford BE, Callahan MD, Corio RL, et al : Oral pathology. Otolaryngol Clin North Am 12 : 29 43, 1979.

3 ) 斎藤英雄, 飯田信長, 山田克彦, 他: 両側口蓋扁桃に転移 を見た肺癌症例. 日気食会誌 $7: 42 \sim 47,1956$.

4 ）猪 初男, 岡本 健, 阿部矯一, 他: 廻盲部より転移せる 口蓋扁桃肉腫の 1 例. 耳喉 $33: 77 \sim 81,1961$ 。

5 ) 金子善一, 杤木照子, 中島利子 : 両側口蓋扁桃の原発悪性 腫瘍を思わせた胃癌の 1 剖検例. 耳喉 36:415～418, 1964.
6 ）船井洋光, 船坂宗太郎, 山口宏也, 他 : 転移性扁桃腫痬の 1 例. 耳喉 $53: 421 \sim 423,1981$.

7 ）田中憲雄, 東家倫夫, 小柳義夫：胃癌よりの転移性口蓋扁 桃腫瘍の 1 症例. 耳鼻 $27: 811 \sim 814,1981$.

8 ）寺尾祐一, 浅井芳江, 濱田稔夫 : Acral Lentiginous Melanoma. 臨皮 $36: 171 \sim 176,1982$.

9 ）三井博文，松浦聖一，大沼秀行，他：転移性口蓋扁桃腫瘍 の 2 症例. 日扁桃誌 $22: 173 \sim 176,1983$.

10）宮原 裕, 馬場克則, 仙波 治, 他：頭頸部領域への転移 癌. 日耳鼻 $86: 951 \sim 957,1983$.

11）周 明仁, 村主好弘, 村上 泰, 他：転移性口蓋扁桃腫瘍 の二症例. 日扁桃誌 $24: 105 \sim 112,1985$.

12）梅田敬子, 馬場駿吉, 横田 明, 他 : 腎癌による口蓋扁桃 転移癌の 1 例. 日扁桃誌 $24: 113 \sim 116,1985$.

13）門脇敬一, 渡部哲二郎, 岩崎利通：胃癌による両側口蓋扁 桃転移癌の 1 症例. 日耳鼻 $89: 1443 \sim 1444,1986$.

14）森 茂樹, 桜井一生, 畔柳久志, 他 : 肺癌による転移性口 蓋扁桃腫瘍の一症例. 耳鼻臨床 $80 ： 1261 \sim 1265,1987$.

15）浅見清孝, 横井 久, 石田和也, 他: 胆霊癌の扁桃転移例. 耳鼻臨床 $81 ： 1755 \sim 1759,1988$.

16）青山志，小沼政子，三上勝也，他：大腸癌上りの口蓋扁 桃転移癌の一例. 日大腸肛門誌 $41: 630,1988$.

17）平間敏晴, 田中淳夫, 長 幹麿, 他: 扁桃転移で発見され た胃癌の 1 例. Gastroenterological Endoscopy 30:2129, 1988.

18）大塚俊夫, 池内恒雄, 岩下明徳, 他 : 扁桃に転移した悪性 黒色腫の 1 例. 皮膚臨床 $31: 452 \sim 453,1989$.

19）持松いずみ, 富田佳代子, 高畑喜延, 他：他領域からの頭 頸部転移症例. 耳鼻 $35: 197 \sim 201,1989$.

20）後藤達哉, 村上匡孝, 中江 進 : 両側口蓋扁桃に転移をみ た大細胞型肺癌症例. 耳喉頭頸 $62: 685 \sim 688,1990$. 
21）森 厚夫, 馬場 恵, 才川義朗, 他 : 化学 - 内分泌療法に 著効をしめした乳癌扁桃転移の 1 例. 日臨外医会誌 増51： 328, 1990.

22）三武明夫, 北村 豊, 吉田洋子, 他 : 根治手術後 1 年にて 扁桃転移により再発した Borrmann 2 型進行胃癌の 1 例. 日消病会誌 $87: 2556,1990$.

23）佐藤玲子, 辺土名仁, 長島道夫 : 口蓋扁桃に転移した胃癌 の 1 例. 耳喉頭頸 $64: 921 \sim 925,1992$.

24）佐伯忠彦, 戸田 茂, 藤岡 博, 他: 口蓋扁桃に転移をき たした肝細胞癌の 1 例. 耳喉頭頸 $64: 747 \sim 751,1992$.

25）永井裕之, 鈴木 亨, 小塚 誠, 他：両側扁桃転移を来し た肺癌の 1 例. 日耳鼻 $95: 766,1992$.

26）松島伸治, 吉川 晃, 山本英希, 他: 口蓋扁桃に転移を来 した肺小細胞癌の 1 例. 日呼外会誌 $7: 608 \sim 612,1993$.

27）坂下勤武, 斉藤 等, 都築秀明, 他 : 転移性扁桃悪性中皮 腫の一治験例. 耳鼻臨床 補63：135～139, 1993.

28）河合晃充, 折田洋造, 山本英一, 他 : 脺癌の扁桃, 舌根部 転移例. 耳鼻臨床 $86: 836 \sim 845,1993$.

29）中川雅文, 相馬新也, 中西文美, 他：口蓋扁桃に転移をみ た肺癌症例. 耳鼻 $41: 597 \sim 600,1995$.
30）秋山優子, 八木正人, 村上匡孝, 他 : 転移性口蓋扁桃腫瘍 の 1 例. 日赤医学 $47: 247 \sim 250,1995$.

31）山内博幸, 西平茂樹, 平野 裕, 他: 胃癌からの転移性口 蓋扁桃腫瘍の 1 例. 耳喉頭頸 $67: 650 \sim 654,1995$.

32）須小 毅, 渡辺哲生, 黒野祐一, 他 : 扁桃転移を来した胃 癌の 1 症例. 口咽科 $8: 77,1995$.

33) Draizin D, Matucci K and Rothfeld S : Bilateral metastatic tonsillar disease due to renal-cell carcinoma. Ear Nose Throat J $57:$ 477 480, 1978.

34) Brownson RJ, Jaques WE, LaMonte SE, et al : Hypernephroma metastatic to the palatine tonsils. Ann Otol Rhinol Laryngol $88: 235 \sim 240,1979$.

35) Warren WH, Faber LP and Gould VE : Neuroendocrine neoplasma of the lung; a clinicopathologic update. J Thoracic Cardiovasc Surg 98 : 321 332, 1989.

$$
\begin{aligned}
& \text { 原稿受付: 平成 } 10 \text { 年 } 4 \text { 月 } 30 \text { 日 } \\
& \text { 原稿採択 : 平成 } 10 \text { 年 } 6 \text { 月 } 3 \text { 日 } \\
& \text { 別刷請求先 : 渡邊昭侣 } \\
& \text { ⿳003-0027 } \\
& \text { 恵佑会札幌病院耳鼻咽喉科 }
\end{aligned}
$$

